\title{
Available and refractory nitrogen in detritus of coastal vascular plants and macroalgae
}

\author{
Robert Buchsbaum ${ }^{1 *}$, Ivan Valiela ${ }^{1}$, Tony Swain ${ }^{2}$, Michelle Dzierzeski $^{1}$, Sarah Allen ${ }^{1}$ \\ ${ }^{1}$ Boston University Marine Program, Marine Biological Laboratory, Woods Hole, Massachusetts 02543, USA \\ ${ }^{2}$ Biological Science Center, Boston University, 2 Cummington Street, Boston, Massachusetts 02215, USA
}

\begin{abstract}
The chemical nature of nitrogenous compounds in detritus both reflects decay processes and influences rates of detrital decomposition. We followed changes in total, available and refractory nitrogen and amino acids during decay of 6 different species of marine plants and macroalgae. Immobilization of nitrogen occurred only in detritus derived from Spartina patens, probably because the decay rates of all other species were too rapid to allow mechanisms fostering nitrogen incorporation into detritus to exceed nitrogen losses. In vascular plants, nitrogen in whole detritus and detrital cell walls was lost more slowly than detrital carbon; in marine algae, there was little difference between rates of nitrogen and carbon loss. Ratios of amino acids: total nitrogen changed very little during decay, suggesting that the chemical transformation of amino nitrogen into heterocyclic rings did not occur. Pools of available nitrogen, as determined by lability to a bacterial protease and extraction in a neutral detergent, generally declined at a faster rate than pools of refractory nitrogen. In the detritus with the slowest overall rate of organic matter loss, there was little difference between rates of available and refractory nitrogen loss, suggesting that carbon rather than nitrogen was more limiting to decomposers in this species and other vascular plants. In $S$. alterniflora detritus, the pool of $N$ associated with lignocellulose actually increased in size during decay, probably because nitrogen becomes bound to lignin. A comparison of the decay rates, nitrogen dynamics, and detrital cell wall chemistry of the plants and algae support the central role of detrital chemistry in controlling rates of decomposition and nitrogen turnover.
\end{abstract}

\section{INTRODUCTION}

The nitrogen content of plant detritus is a major influence on rates of detrital decay and on the growth rates of detritivores (Fenchel 1977, Godschalk \& Wetzel 1978, Melillo et al. 1982, Tenore et al. 1984, Aumen et al. 1985, Rietsma et al. 1988). At the same time, decay processes influence the turnover of nitrogen in detritus, its availability to detritivores, and the types of nitrogen compounds present. After the initial leaching of labile compounds (Godshalk \& Wetzel 1978, Valiela et al. 1985), nitrogen is simultaneously lost from detritus by mineralization and incorporated into detritus from the surrounding environment (Odum et al. 1979, Tenore \& Rice 1980, Melillo et al. 1982, Rice 1982). When incorporation rates exceed rates of mineralization, there is a net gain ('immobilization') of nitrogen in the detritus.

\footnotetext{
- Present address: Massachusetts Audubon Society, 346 Grapevine Rd., Wenham, Massachusetts 01984, USA
}

The balance between nitrogen incorporation and mineralization in detritus is determined by a number of factors. Incorporation of nitrogen into detritus can be promoted by microbial uptake (Hobbie \& Lee 1980, Lee et al. 1980, Marinucci et al. 1983, Paerl 1984, Rice \& Hanson 1984, Wheeler \& Kirchman 1986). Nitrogen can also be incorporated into detritus by the protein-binding activites of several detrital cell wall constituents: lignin and related phenolic compounds, polysaccharides, and 'extensin' proteins (Siegel \& Siegel 1973, Van Sumere et al. 1975, Rice 1982, Benner et al. 1984, McNeil et al. 1984, Wilson et al. 1985). Mineralization rates of nitrogen in detritus are affected by availability of nitrogen and lability of detrital carbon to microbial enzymes. Availability of nitrogen is a function of the extent of nitrogen binding into refractory complexes (Odum et al. 1979, Rice 1982). Lability of detrital carbon is largely a function of quantity and quality of lignocellulose in detrital cell walls (Benner et al. 1984. Wilson et al. 1985). 
In this paper we examine decomposition rates and nitrogen dynamics of representative marine plants and macroalgae that were incubated in their natural habitat. First, we compare decay rates and changes in total nitrogen and amino acid content during decay, Second, we follow the pools of available and refractory nitrogen and amino acids over time in the various types of detritus using 2 measures of availability: incubation with a bacterial protease and extraction by a detergent. This would show the extent to which labile nitrogen compounds either in the water column or the original detritus become incorporated into refractory constituents, such as humic acids, during decay (Rice 1982). We also measure phenolics in different types of detritus because of their potential role in nitrogen binding. The comparisons among different species of plants and macroalgae incubated in situ enable us to relate rates of nitrogen transformations to detrital carbon and nitrogen chemistry and to habitat differences among the different species.

\section{METHODS}

Preparation of different types of detritus. We selected several types of marine vascular plants and macroalgae to test the influence of detrital chemistry on decomposition rates and nitrogen dynamics. The species selected were the marsh grasses Spartina alterniflora (tall and short ecophenotypes) and S. patens; a submerged angiosperm, Zostera marina; a chlorophyte, Ulva lactuca; a phaeophyte, Fucus vesiculosis; and a rhodophyte, Gracilaria tikvahiae. These provide a range of types and concentrations of various cell wall constituents (Siegel \& Siegel 1973, Harris \& Hartley 1980). The method of preparing the detritus depended on the species. Our goal was to produce detritus that chemically resembled that produced under field conditions as closely as possible. Living leaves and aboveground stems of salt marsh grasses were collected when they were beginning to senesce in late October. These were air-dried at room temperature for $2 \mathrm{wk}$ to produce detritus. Detritus of $Z$. marina was obtained by clipping living shoots above the sediment in early November and again in May. These shoots started to senesce after several weeks incubation in the field. Detritus from the 3 species of macroalgae was created by freezing whole living fronds at $-80^{\circ} \mathrm{C}$.

We did not air-dry detritus of Zostera marina and the macroalgae because these species normally senesce under water. We wanted to avoid an artifact, the oxidative coupling of phenolics and proteins in leaves of airdrying plants (Van Sumere et al. 1975), that artifically increases the difficulty of extracting proteins. In addition, air-drying is an unreliable method of causing senescence in intertidal algae (unpubl.)
The detritus created in the aforementioned manner was weighed and placed in $30 \times 10 \mathrm{~cm}$ nylon mesh bags ( $3 \times 2$ mesh size). Each bag had a stiff plastic ring sewn across its equator to keep the mesh from collapsing around the detritus. Samples of Spartina alterniflora and $S$. patens were from an earlier study (Valiela et al. 1985) in which enough bags were set out to allow duplicate sampling at each time interval. Fucus vesiculosis was also sampled in duplicate. Zostera marina, Ulva lactuca, and Gracilaria tikvahiae were sampled in triplicate.

Field incubation of detritus. We incubated each type of detritus in the habitat in which it would most likely decompose naturally. Spartina detritus was incubated on the surface of a salt marsh (Great Sippewissett Marsh, Falmouth, Massachusetts, USA) and was placed out in the field in late autumn. Each Spartina sp. was incubated in the habitat where it was collected in the marsh, i.e. tall $S$. alterniflora along creekbanks, etc. Valiela et al. (1985) found little fragmentation loss of detrital material from these litter bags. The other types of detritus were all submerged in a protected bay (Great Harbor, Woods Hole, Massachusetts) where they rested on the surface of the sediment at a depth of about $2 \mathrm{~m}$ below mean low water. Two sets of incubations of Zostera marina were carried out, one beginning in November and another in May. Only the November $Z$. marina was used for later chemical analysis, since this is a time when it loses biomass in New England and therefore produces large amounts of detritus (Thayer et al. 1984, ThoneMiller \& Harlin 1984). The marine algae litterbags were incubated in May.

At appropriate time intervals that varied with the type of detritus, 2 or 3 bags of each type of detritus were brought back to the lab, the detritus washed gently in running seawater to remove dirt, and then dried at $45^{\circ} \mathrm{C}$. They were then weighed to determine weight loss and a subsample was ground through a 60 mesh screen in a Wiley mill.

Nitrogen content and availability. Nitrogen dynamics in the different types of decomposing detritus was studied by analyzing for total and amino nitrogen and for nitrogen fractions that differed in their availability to decomposers. Total nitrogen and carbon were measured by a Perkin-Elmer C:H:N analyzer. Values are expressed as $\mathrm{g}$ nitrogen remaining per $100 \mathrm{~g}$ initial ash free dry weight (AFDW) of detritus. This is a measure of the pool of nitrogen that remains in the detritus at different times during its decay, assuming that we start with $100 \mathrm{~g}$ of each type of detritus. The advantage of expressing the data in this way is that the size of the nitrogen pools in different types of detritus can be compared directly with each other. The calculation used to obtain the values was: 
g $\mathrm{N}$ remaining per $100 \mathrm{~g}$ initial detritus $=(\% \mathrm{~N}$ per AFDW at time $) \times(\%$ of the initial organic matter still remaining at time)/100.

(If each value is then divided by the initial $\mathrm{N}$ concentration and multiplied by 100 , the result is 'absolute $N$ ', the \% of the original nitrogen still remaining).

Total amino acids were measured by hydrolyzing detritus in $6 \mathrm{~N} \mathrm{HCl}$ at $100^{\circ} \mathrm{C}$ for $20 \mathrm{~h}$ and then determining the total amino acids released using the ninhydrin reagent (Marks et al. 1985). This assay detects primary amines and thus eliminates the interference by phenolics that occurs in the Lowry and similar protein assays (Rice 1982). The interference by non-amino nitrogen compounds with the ninhydrin procedure is negligible (Marks et al. 1985).

We measured available amino nitrogen in 2 ways: an in vitro digestibility procedure (modified from Choo et al. 1981) and a detergent extraction (Goering \& Van Soest 1970). In the in vitro digestion, available amino acids were defined as that hydrolyzed from the detritus at $20^{\circ} \mathrm{C}$ after $20 \mathrm{~h}$ in artificial seawater by a nonspecific bacterial protease from Streptomyces griseus (Sigma Chemical Company). A $25 \mathrm{mg}$ sample of detritus was incubated in $2 \mathrm{ml}$ of a $0.2 \%$ solution of the protease in artifical seawater. Sodium azide $(0.1 \%)$ was added to the seawater to reduce microbial activity during incubation. The release of amino acids by the protease generally reached an asymptote within $5 \mathrm{~h}$ of incubation, but the incubations were allowed to run for $20 \mathrm{~h}$ to insure complete hydrolysis of all available protein. Preliminary assays showed that neither greater concentrations of the protease nor the presence of a cellulase enhanced the amount of protein hydrolyzed. Following the enzymatic hydrolysis, the residue from the assay was washed $4 x$ in artificial seawater to remove the protease and any amino acids and peptides solubilized by the protease. The residue was then assayed for amino acids by the ninhydrin procedure described earlier. The result was taken to be protease-refractory amino acids. The available amino acid fraction was the difference between refractory and total amino acids.

We carried out detergent extractions on all initial detritus and the oldest detritus of each species for which the required amount of material still remained. Available amino acids were extracted by a neutral detergent reagent (Goering \& Van Soest 1970). We assumed that nitrogen and amino acids not solubilized by the detergent were associated with cell walls (i.e. neutral detergent fiber, NDF). We adapted the procedure of Goering $\&$ Van Soest for smaller quantities of materials. Samples of $100 \mathrm{mg}$ of detritus were placed in test tubes along with $10 \mathrm{ml}$ of neutral detergent reagent $(30 \mathrm{~g}$ sodium lauryl sulfate, $18.61 \mathrm{~g}$ disodium EDTA, $6.81 \mathrm{~g}$ sodium borate, $4.56 \mathrm{~g}$ anhydrous disodium hydrogen phos- phate, $10 \mathrm{ml}$ 2-ethylene glycol monoethyl ether in 11 distilled water, $\mathrm{pH} 7.0$ ) $+0.2 \mathrm{ml}$ decahydronapthalene and $50 \mathrm{mg}$ sodium sulfate. The tubes were heated from the bottom to $100^{\circ} \mathrm{C}$ in a dry bath and the detergent was refluxed within the tube by cooling the top of the tube. After $1 \mathbf{h}$, the detergent reagent was removed by centrifugation. The residue was washed by filtration through sintered glass $2 \times$ with $10 \mathrm{ml}$ water at $100{ }^{\circ} \mathrm{C}$ and $1 \times$ with methanol. We assayed for total nitrogen (NDF-N) and amino acids (NDF-AA) in this residue.

To further examine the refractory fraction of detrital cell walls, we repeated the detergent extraction using an acid detergent reagent in place of the neutral detergent (Goering \& Van Soest 1970). The acid detergent reagent consistend of $10 \mathrm{ml}$ of acid detergent solution (49.04 g sulfuric acid and $20 \mathrm{~g}$ cetyl trimethylammonium bromide in $1 \mathrm{l}$ distilled water) $+0.2 \mathrm{ml}$ decahydronapthalene. Acid detergent fiber (cellulose + lignin + extensin proteins) was also analyzed for nitrogen and amino acid content (ADF-N and ADFAA). Available, refractory, and total amino acids are expressed as $\mathrm{g}$ amino acids remaining per $100 \mathrm{~g}$ initial AFDW of detritus, the same calculation we used for expressing nitrogen.

'Lignins' and phenolic constituents. Insoluble phenolics and related condensation products associated with cell walls of both vascular plants and algae were measured as acid detergent 'lignin' (Goering \& Van Soest 1970). We put lignin in quotes here because algae (and perhaps Zostera marina) lack true lignin (Siegel \& Siegel 1973, Swain 1979, Ragan \& Glombitza 1986). The refractory material remaining after treatment of algal acid detergent fiber with $72 \%$ sulfuric acid at $100^{\circ} \mathrm{C}$ for $1 \mathrm{~h}$ includes refractory material that may or may not be phenolic in nature (Tenore et al. 1984, Ragan \& Glombitza 1986).

Soluble phenolics were measured by the Folin-Denis procedure after extraction of detritus in $80 \%$ methanol (Swain \& Goldstein 1964).

Ash content. All values of chemical constituents are expressed as ash-free dry weight (AFDW). Ashing was carried out by combustion of samples at $500^{\circ} \mathrm{C}$ for $3 \mathrm{~h}$ (Allen et al. 1974).

Statistical analysis. Rates of loss of total organic matter, total nitrogen, protease refractory protein and available protein were compared using a test for homogeneity of slopes. This test was an analysis of covariance modeled as a multiple regression (SPSSPC, forced entry method). The dependent variables were log-transformed before analysis. Only statistically significant slopes were compared. We used the same statistical procedure to compare the rates of losses of Van Soest fiber fractions of Spartina alterniflora (tall form). This was the only species where Van Soest fiber analysis included more than 2 time points. 


\section{RESULTS}

\section{Rates of weight loss}

The rates of weight loss of different types of detritus varied from complete disappearance within a month (red and green algae) to less than complete loss even after 2 yr (marsh grasses; Fig. 1). The rates of loss of the brown alga Fucus vesiculosis and the seagrass Zostera marina were intermediate between those of other algae and marsh grasses. Detritus from $Z$. marina incubated in the spring-summer lost weight slightly more rapidly than that incubated in autumn-winter.

\section{Changes in total nitrogen pools during decay}

The rate at which net nitrogen loss occurred in the different types of detritus followed the same relative pattern as weight loss, i.e. Spartina patens $<S$. alterniflora < Zostera marina < marine algae (Fig. 2). The only types of detritus that clearly immobilized nitrogen (i. e. showed an absolute increase in the nitrogen at

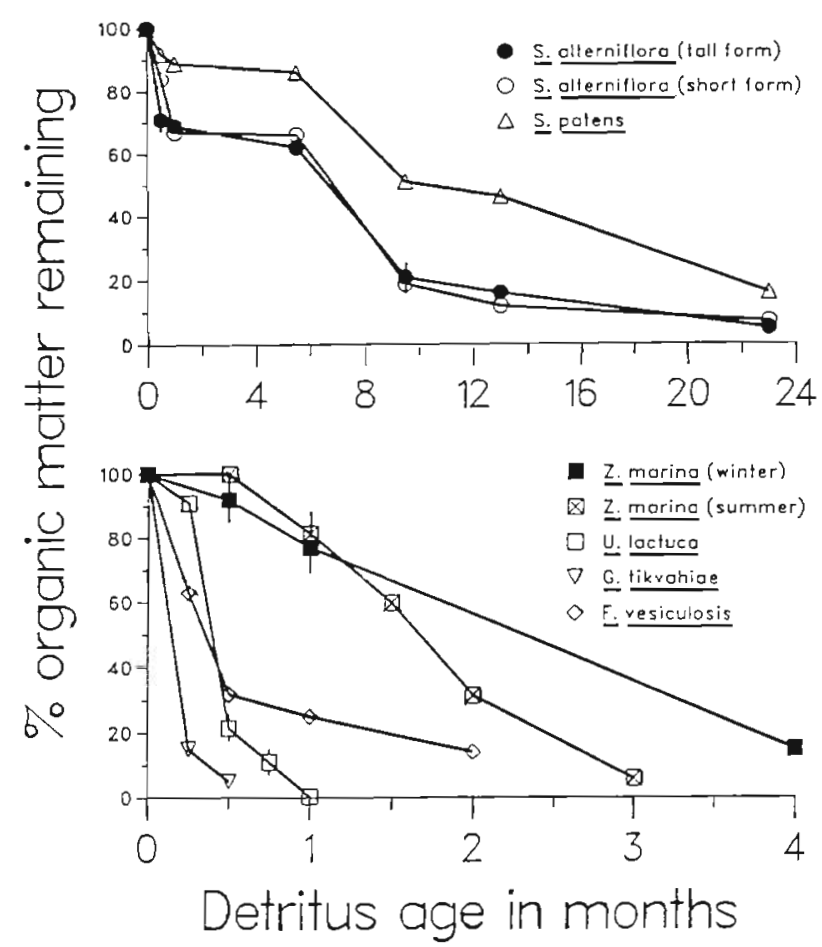

Fig. 1. Percent of initial organic matter remaining during the course of decay of detritus placed in litterbags and incubated in situ in a salt marsh (top) or on the surface of the sediment in a protected marine bay (bottom). Top graph from Valiela et al. (1985). Month 0 in top graph is November. Month 0 for bottom graph is May, except for Zostera marina (winter) in which time 0 is November. Values are means \pm standard errors of duplicate or triplicate samples, as indicated in 'Methods' SE only drawn when larger than size of symbol some point during decay) were detritus from $S$. alterniflora between 1 and 5.5 mo and $S$. patens between 0 and $5.5 \mathrm{mo}$ (Fig. 2, top)

A comparison of slopes of the lines representing rates of organic matter and nitrogen loss indicates whether nitrogen compounds were more refractory to decay than total organic matter (Table 1). Except for a brief leaching period in detritus of Spartina alterniflora (obvious from Figs. 1 \& 2), nitrogen declined at a significantly slower rate than total organic matter in the marsh grasses. In Zostera marina and the algae, nitrogen and organic matter declined at about the same rate, based on the lack of difference between slopes (Table 1).

Total, available, and refractory amino acids measured by protease hydrolysis

The 3 species of marine algae had higher initial concentrations of total amino acids than the vascular plants (Fig. 3, solid circles, time 0). Particularly high concentrations of total amino acids, about $30 \%$ AFDW

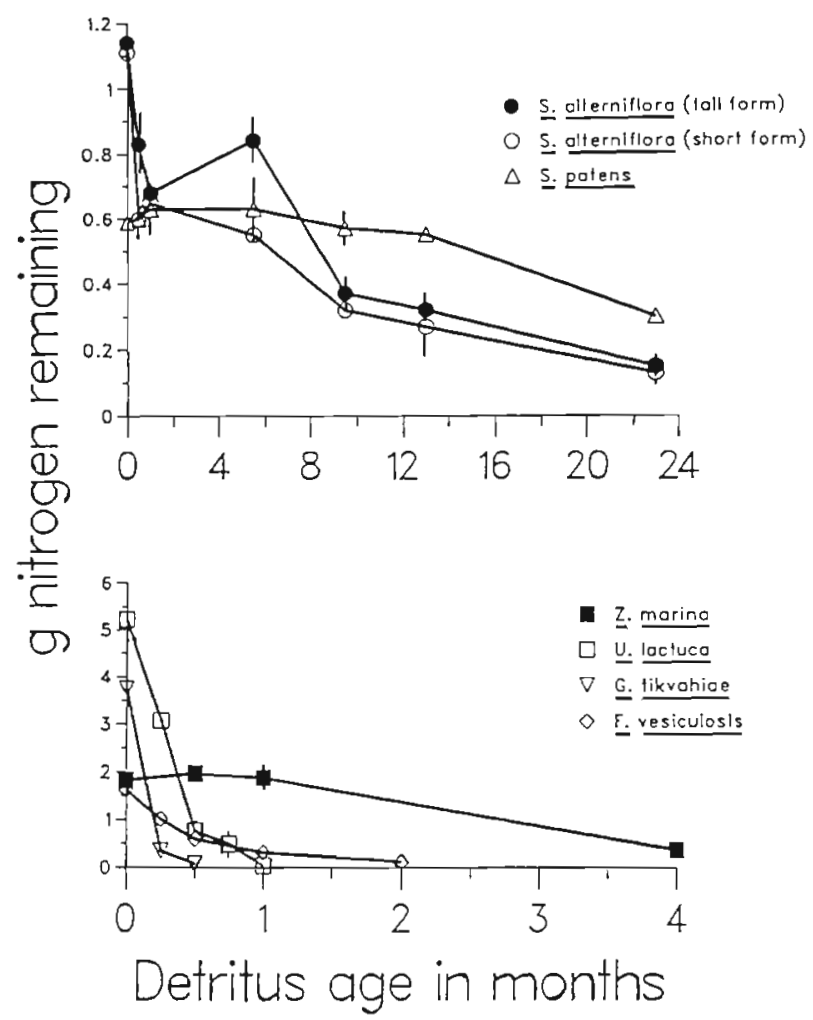

Fig. 2. Changes in amount of nitrogen in detritus during the course of decay. Values are expressed as $g( \pm S E)$ nitrogen that still remained at various times during decay, assuming we started with $100 \mathrm{~g}$ of detrital organic matter at time 0 . Pool calculations normalized to $100 \mathrm{~g}$ organic matter of detritus at time 0 so that direct comparison between different types of detritus can be made 
Table 1. Comparison of slopes of regression equations between rate of weight loss of detritus and loss of nitrogen. Raw data converted to the natural $\log$ of the ratio of amount remaining at time t:initial amount present \pm standard error of the regression coefficient. Slopes compared for parallelism by analysis of covariance modeled as a multiple regression

\begin{tabular}{|lccc|}
\hline Detritus & & Slopes & \\
& Dry weight & Total nitrogen & ANCOVA \\
\hline Spartina alterniflora (tall form) & $-0.130 \pm 0.009$ & $-0.083 \pm 0.008$ & $p<0.001$ \\
S. alterniflora (short form) & $-0.129 \pm 0.011$ & $-0.083 \pm 0.006$ & $\mathrm{p}<0.005$ \\
S. patens & $-0.079 \pm 0.008$ & $-0.027 \pm 0.005$ & $\mathrm{p}<0.001$ \\
Zostera marina & $-0.488 \pm 0.041$ & $-0.557 \pm 0.076$ & NS \\
Ulva lactuca & $-4.558 \pm 0.616$ & $-4.262 \pm 0.520$ & NS \\
Gracilaria tikvahiae & $-6.623 \pm 1.000$ & $-7.824 \pm 0.656$ & NS \\
Fucus vesiculosis & $-1.019 \pm 0.120$ & $-1.386 \pm 0.124$ & NS p $<0.1$ \\
\hline
\end{tabular}

occurred in Ulva lactuca and Gracilaria tikvahiae. In contrast, the 3 types of detritus from marsh grasses contained less than $10 \%$ amino acids at time 0 .

Rapid initial losses of amino acids, probably due to leaching, occurred in Spartina alterniflora and the 3 species of algae (Fig. 3). This was followed by a period of slower rates of decline. Leaching of amino acids did not occur in detritus of $S$. patens and Zostera marina. In both these species, the pool of total amino acids actually increased above that initially present before eventually declining.

The amino acids pools from vascular plant detritus were initially more refractory to protease hydrolysis than that from red and green algae detritus (Fig. 3, open circles compared to solid circles). About half the amino acid pool in initial detritus from vascular plants
Fig. 3. Changes in the pools of total amino acids and amino acids refractory to a bacterial protease during detrital decay. Values are means \pm SE of duplicate or triplicate samples as indicated in 'Methods'. Amino acids released by the protease are the difference between total and refractory amino acids. Pool calculations normalized to $100 \mathrm{~g}$ organic matter of detritus at time 0
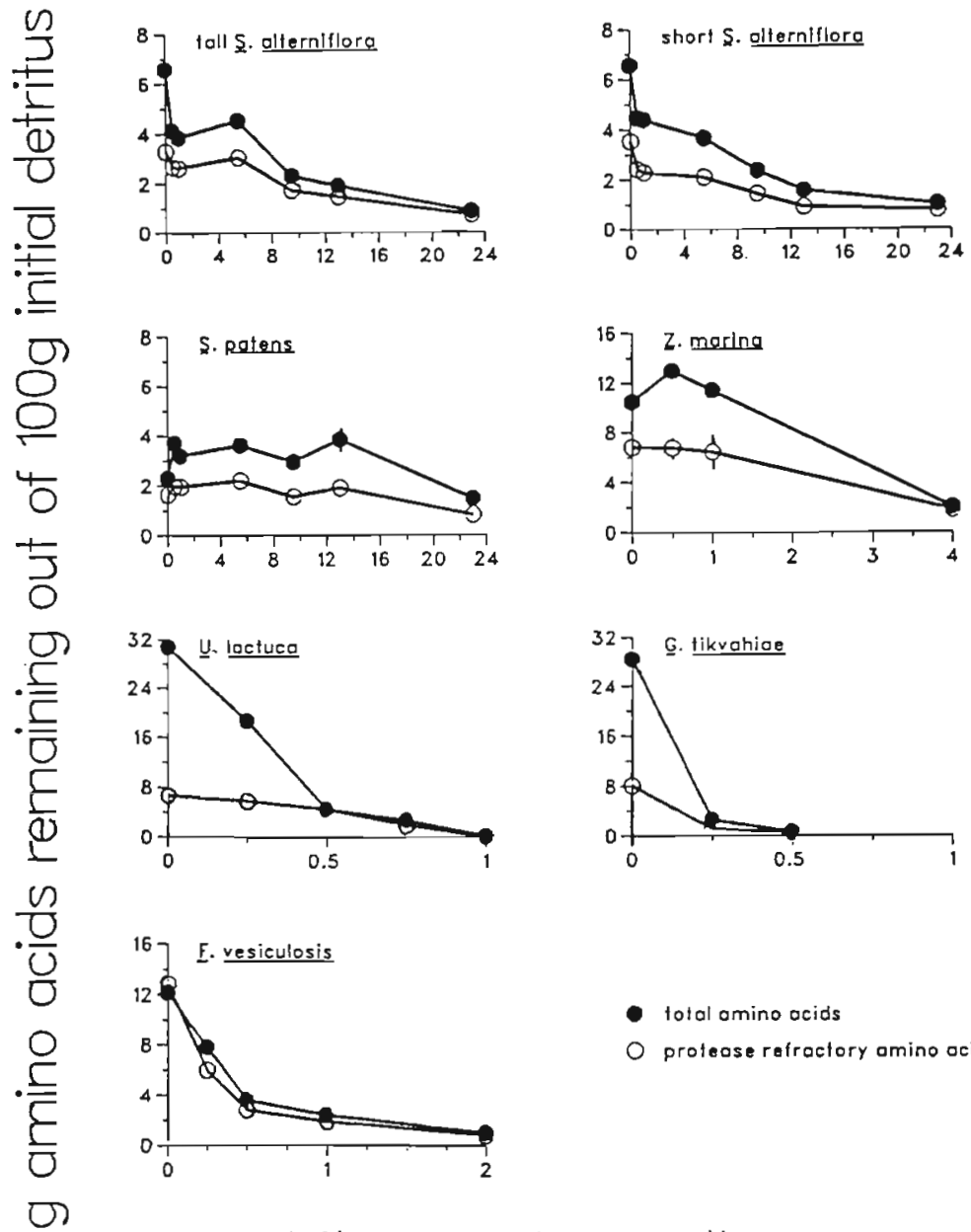

- total amino acids

O proteose refroctory amino acios 
was refractory to hydrolysis by protease compared to less than one third for detritus derived from Ulva lactuca and Gracilaria tikvahiae. The amino acids in initial detritus from Fucus vesiculosis were completely refractory to protease hydrolysis.

Available amino acids were lost significantly more rapidly than refractory amino acids in detritus from Spartina alterniflora, Zostera marina, and Gracilaria tikvahiae (Table 2). In S. patens, the lack of linearity in the rate of loss of available amino acids precluded statistical comparison between slopes of available and refractory amino acids (Table 2). An examination of Fig. 3 suggests that available and refractory amino acids change at roughly similar, relatively slow rates in this species. Very little of the relatively large initial pool of available amino acids remained after 2 wk of incubation of Ulva lactuca and G. tikvahiae. Fucus vesiculosis had very little available amino acids throughout its 2 mo decay period.

\section{Available amino acids measured by detergent extraction}

The amount of available amino acids, as determined by neutral detergent extraction, correlated well with the results using the protease (Fig. 4; $\mathrm{r}=0.909$, $\mathrm{p}<0.01$ ). The neutral detergent generally extracted slightly more amino acids than the protease, particularly in those types of detritus that were relatively low in amino acids (note points above 1:1 line in Fig. 4).

In most fypes of detritus, the rate of loss of the neutral detergent soluble amino acids was about the same (Spartina alterniflora, Ulva lactuca, Gracilaria tikvahiae, Fucus vesiculosis) or slightly more rapid (Zostera marina) than the rate of loss of organic matter (Table 3 compared with Fig. 1). The one notable exception was S. patens, in which $54 \%$ of the original neutral detergent soluble amino acid pool was still present after 23 mo of decay, a time when only $16 \%$ of the organic matter remained (Table 3 ).

\section{Nitrogen associated with NDF}

Levels of nitrogen and amino acid associated with cell walls (NDF-N and NDF-AA) levels were initially lower and declined less rapidly during decay in marsh grasses compared to the algae (Table 4). Spartina alterniflora still contained 25 to $30 \%$ of its original cell wall nitrogen at 23 mo (Table 4 ) when less than $10 \%$ of its organic matter remained. All 3 types of marine algal

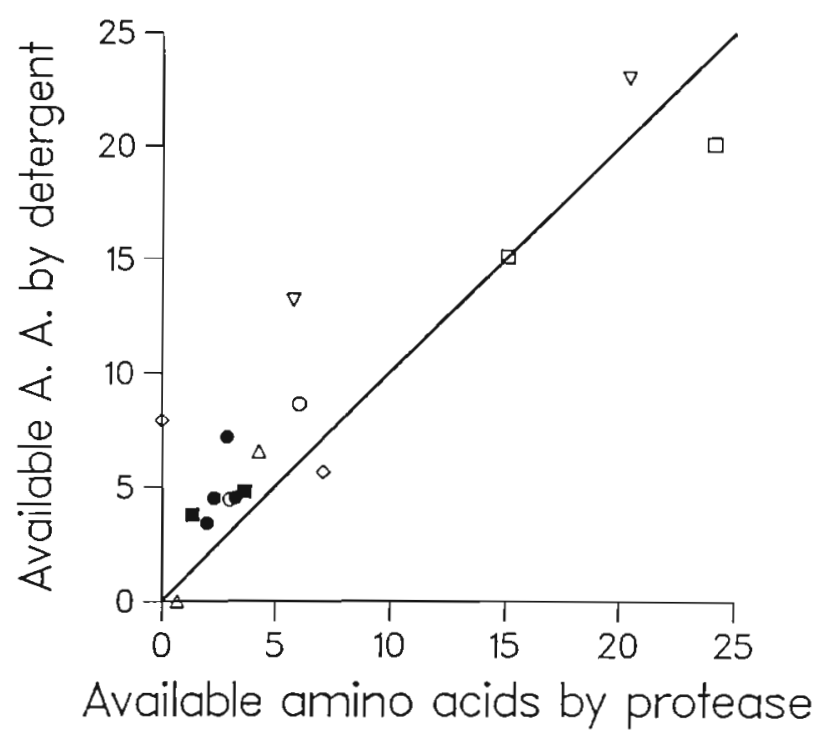

Fig. 4. \% available amino acids that can be extracted by a neutral detergent expressed as a function of the \% available amino acids that are extracted by the protease. Values for each type of detritus represent different times of decay. $1: 1$ line is drawn to indicate point where no difference between the 2 methods exists. df $=14, \mathrm{p}<0.01$. Symbols as in Figs. $1 \& 2$

Table 2. Comparison of slopes of regression equations between rate of loss of protease-refractory protein and available protein. Raw data converted to the natural $\log$ of the ratio of amount remaining at time $t$ :initial amount present \pm standard error of the regression coefficient. Slopes compared for parallelness by analysis of covariance modeled as a multiple regression. ${ }^{\bullet}$ Relationship between the independent variable (time) and the dependent variable was not linear at the $\alpha=0.05$ level

\begin{tabular}{|c|c|c|c|}
\hline \multirow[t]{2}{*}{ Detritus } & \multicolumn{2}{|c|}{ Slopes } & \multirow[t]{2}{*}{ ANCOVA } \\
\hline & Protease-refractory protein & Available protein & \\
\hline Spartina alterniflora (tall form) & $-0.066 \pm 0.008$ & $-0.113 \pm 0.012$ & $\mathrm{p}<0.005$ \\
\hline S. alterniflora (short form) & $-0.062 \pm 0.007$ & $-0.101 \pm 0.006$ & $p<0.001$ \\
\hline S. patens & $-0.032 \pm 0.008$ & $-0.012 \pm 0.017^{\circ}$ & - \\
\hline Zostera marina & $-0.357 \pm 0.058$ & $-0.856 \pm 0.113$ & $p<0.005$ \\
\hline Ulva lactuca & $-3.670 \pm 0.623$ & $-4.999 \pm 0.559$ & NS \\
\hline Gracilaria tikvahiae & $-5.785 \pm 0.689$ & $-9.220 \pm 0.815$ & $p<0.05$ \\
\hline Fucus vesiculosis & $-1.285 \pm 0.158$ & No avail. prot. & - \\
\hline
\end{tabular}


detritus contained $14 \%$ or less of their original cell wall nitrogen when they had decayed to about $10 \%$ of their original organic matter. The initial concentrations of NDF-N and NDF-AA in Zostera marina were more similar to those of marine algae than marsh plants. After 4 mo of decay, however, it resembled the marsh grasses, in that $28 \%$ of its NDF-N remained along with $15 \%$ of its organic matter.

Changes in the $\mathrm{C}: \mathrm{N}$ ratios of cell walls during decay were much more pronounced in marsh grasses than in Zostera marina or the marine algae (Table 4). C:N ratios of marsh grass detritus were substantially higher at time 0 than $Z$. marina and algae detritus, but then declined steeply during decay. In contrast $C: N$ ratios of Z. marina, Ulva lactuca and Gracilaria tikvahiae changed very little during decay and that of Fucus vesiculosis actually increased during decay. These results show a relative enrichment in cell wall nitrogen compared to cell wall carbon during the decay of marsh grasses but not of $Z$. marina or the algae.

The pools of amino acids associated with cell walls either declined at a more rapid rate than pools of cell wall nitrogen (tall Spartina alterniflora, S. patens, Zostera marina) or at about the same rate (all others, Table 4). The regression coefficient of the line representing loss of cell wall nitrogen in tall $S$. alterniflora $(-0.053 \pm 0.011)$ was only about half that of the line representing cell wall amino acids $(-0.130 \pm 0.014)$; the difference is statistically significant $\mathrm{p}<0.001)$. A more rapid decline of amino acids compared to nitrogen suggests that more of the remaining cell wall nitrogen is either inorganic or in non-amino heterocyclic complexes.

\section{Nitrogen associated with ADF}

Acid detergent fiber from marsh grass detritus was initially lower in nitrogen and (like NDF fractions) lost nitrogen more slowly during decay compared to ADF of other types of detritus (Table 5). Spartina patens and Zostera marina contained 75 to $100 \%$ of their initial ADF-N even after losing about $85 \%$ of their initial

Table 3. Available amino acids measured by extraction into neutral detergent reagent. Data is expressed as grams of amino acids remaining $( \pm S E)$ in the detritus after different periods of decay assuming that we started with $100 \mathrm{~g}$ detritus

\begin{tabular}{|lcc|}
\cline { 2 - 3 } Detritus & $\begin{array}{c}\text { Age } \\
(\mathrm{mo})\end{array}$ & $\begin{array}{c}\text { Amino acids } \\
(\mathrm{g})\end{array}$ \\
\hline Spartina alterniflora (tall form) & 0 & $7.50 \pm 0.18$ \\
& 1 & $2.68 \pm 0.23$ \\
& 5.5 & $4.29 \pm 0.23$ \\
& 9.5 & $1.71 \pm 0.31$ \\
S. alterniflora (short form) & 23 & $0.53 \pm 0.15$ \\
& 0 & $4.42 \pm 0.54$ \\
S. patens & 13 & $0.65 \pm 0.04$ \\
& 0 & $1.80 \pm 0.39$ \\
Zostera marina & 23 & $0.95 \pm 0.01$ \\
Ulva lactuca & 0 & $10.60 \pm 1.06$ \\
Gracilaria tikvahiae & 4 & $0.79 \pm 0.02$ \\
Fucus vesiculosis & 0 & $20.17 \pm 0.90$ \\
& 0.75 & $1.55 \pm 0.99$ \\
& 0 & $21.92 \pm 0.79$ \\
& 0.5 & $0.50 \pm 0.02$ \\
& 0 & $6.15 \pm 1.40$ \\
& 2 & $0.84 \pm 0.10$ \\
\hline
\end{tabular}

Table 4. Nitrogen and amino acids in neutral detergent fiber (NDF). Values are grams \pm standard errors of NDF, nitrogen in NDF (NDF-N), and amino acids in NDF (NDF-AA) remaining in the detritus assuming we started with $100 \mathrm{~g}$ of detritus. Carbon:nitrogen ratios (C:N) of NDF are also presented

\begin{tabular}{|lccllcl}
\hline Detritus & Age (mo) & g NDF & & g NDF-N & g NDF-AA & C:N \\
\hline Spartina alterniflora (tall form) & 0 & $62.7 \pm 2.2$ & $0.16 \pm 0.04$ & $2.05 \pm 0.02$ & $189 \pm 37$ \\
& 1 & $49.4 \pm 0.4$ & $0.10 \pm<0.01$ & $1.52 \pm 0.11$ & $226 \pm 1$ \\
& 5.5 & $43.2 \pm 0.3$ & $0.16 \pm 0.03$ & $1.69 \pm 0.11$ & $127 \pm 19$ \\
& 9.5 & $12.5 \pm 1.1$ & $0.12 \pm<0.01$ & $0.86 \pm 0.11$ & $39 \pm 5$ \\
S. alterniflora (short form) & 23 & $1.5 \pm<0.1$ & $0.04 \pm<0.01$ & $0.11 \pm 0.05$ & $19 \pm 1$ \\
S. patens & 0 & $68.4 \pm 2.3$ & $0.33 \pm 0.06$ & $2.11 \pm 0.52$ & $96 \pm 13$ \\
& 13 & $7.4 \pm 0.4$ & $0.10 \pm 0.01$ & $0.65 \pm 0.14$ & $28 \pm 2$ \\
Zostera marina & 0 & $68.0 \pm 0.9$ & $0.21 \pm 0.01$ & $2.95 \pm 0.32$ & $155 \pm 1$ \\
& 23 & $9.8 \pm 0.2$ & $0.10 \pm 0.01$ & $0.46 \pm 0.10$ & $41 \pm 2$ \\
Ulva lactuca & 0 & $45.0 \pm 5.0$ & $0.67 \pm 0.02$ & $6.04 \pm 0.38$ & $28 \pm<1$ \\
Gracilaria tikvahiae & 4 & $9.9 \pm 0.3$ & $0.19 \pm 0.01$ & $1.42 \pm 0.10$ & $23 \pm 1$ \\
Fucus vesiculosis & 0 & $34.2 \pm 0.5$ & $1.26 \pm 0.03$ & $8.73 \pm 0.01$ & $10 \pm<1$ \\
& 0.75 & $4.1 \pm<0.1$ & $0.18 \pm<0.01$ & $1.61 \pm 0.72$ & $12 \pm 2$ \\
& 0 & $23.0 \pm 3.0$ & $0.57 \pm 0.02$ & $4.84 \pm 0.22$ & $21 \pm 2$ \\
& 0.50 & $0.7 \pm 0.1$ & $0.02 \pm<0.01$ & $0.15 \pm 0.03$ & $15 \pm 2$ \\
& 0 & $27.1 \pm 0.9$ & $0.59 \pm 0.06$ & $4.27 \pm 0.86$ & $22 \pm 1$ \\
\end{tabular}


organic matter. Detritus of tall S. alterniflora actually incorporated nitrogen into ADF between 5.5 and 9.5 mo, as indicated by the greater than $100 \%$ of the initial concentration at those times. In contrast, the percent of the initial ADF- $N$ pool still remaining in old detritus from Ulva lactuca and Fucus vesiculosis was about the same as the percent of the original organic matter remaining at the same time.

The C:N ratio of ADF from both Zostera marina and the marsh grasses declined steeply during decay showing that the lignocellulose fraction of vascular plant detritus lost carbon more rapidly than nitrogen. The lack of change in the $\mathrm{C}: \mathrm{N}$ ratio of algae ADF during decay indicates that carbon and nitrogen are lost at about the same rate.

Amino acids (ninhydrin positive material) were still present in ADF (Table 5). These must be tightly bound into the lignocellulose matrix since they were only extractable by hot $6 \mathrm{M} \mathrm{HCl}$. These amino acids represented between 30 to $90 \%$ of the cell wall amino acids in the different types of detritus (compare NDFAA in Table 4 with the ADF-AA in Table 5).

Table 5. Nitrogen and amino acids in acid detergent fiber (ADF). Values are grams \pm standard errors of $A D F$, nitrogen in $A D F$ $(A D F-N)$, and amino acids in ADF (ADF-AA) remaining in the detritus assuming we started with $100 \mathrm{~g}$ of detritus. Carbon:nitrogen ratios $(\mathrm{C}: N)$ of ADF are also presented

\begin{tabular}{|lccccc}
\hline Detritus & Age (mo) & g ADF & g ADF-N & g ADF-AA & C:N \\
\hline Spartina alterniflora (tall form) & 0 & $29.2 \pm 2.5$ & $0.09 \pm 0.01$ & $0.85 \pm 0.23$ & $146 \pm 1$ \\
& 1 & $25.9 \pm 2.1$ & $0.05 \pm 0.01$ & $0.77 \pm 0.13$ & $225 \pm 2$ \\
& 5.5 & $22.2 \pm 0.2$ & $0.11 \pm 0.02$ & $0.89 \pm 0.04$ & $96 \pm 12$ \\
& 9.5 & $8.9 \pm 0.1$ & $0.13 \pm 0.01$ & $0.62 \pm 0.16$ & $27 \pm 3$ \\
S. alterniflora (short form) & 23 & $1.0 \pm<0.1$ & $0.03 \pm 0.01$ & not done & $15 \pm 4$ \\
S. patens & 0 & $36.1 \pm 1.6$ & $0.16 \pm 0.01$ & $0.90 \pm<0.1$ & $103 \pm 3$ \\
& 13 & $5.4 \pm 0.3$ & $0.08 \pm 0.01$ & $0.34 \pm 0.02$ & $24 \pm<1$ \\
Zostera marina & 0 & $34.8 \pm<0.1$ & $0.14 \pm<0.01$ & $1.18 \pm 0.28$ & $116 \pm<1$ \\
& 23 & $6.9 \pm<0.1$ & $0.11 \pm 0.01$ & $0.17 \pm 0.04$ & $30 \pm 2$ \\
Ulva lactuca & 0 & $24.4 \pm 1.3$ & $0.15 \pm 0.02$ & $1.99 \pm 0.21$ & $69 \pm 8$ \\
Gracilaria tikvahiae & 4 & $9.5 \pm 0.3$ & $0.17 \pm 0.01$ & $1.01 \pm 0.04$ & $25 \pm 1$ \\
Fucus vesiculosis & 0 & $24.9 \pm 4.4$ & $0.96 \pm 0.12$ & $8.23 \pm 0.66$ & $10 \pm 1$ \\
& 0.75 & $4.1 \pm 0.5$ & $0.15 \pm 0.02$ & $0.75 \pm 0.28$ & $11 \pm<1$ \\
& 0 & $9.1 \pm 2.6$ & undetectable & $1.09 \pm 0.51$ & 1 \\
& 0.50 & $0.6 \pm<0.1$ & $0.02 \pm<0.01$ & $0.82 \pm 0.15$ & $17 \pm 2$ \\
& 0 & $37.1 \pm 3.1$ & $0.70 \pm 0.11$ & $1.87 \pm 0.19$ & $25 \pm 1$ \\
\hline
\end{tabular}

Table 6. Nitrogen in acid detergent 'lignin' Values are grams \pm standard errors of 'lignin' and nitrogen in 'lignin' (lignin- $N$ ) remaining in the detritus assuming we started with $100 \mathrm{~g}$ of detritus. Carbon: nitrogen ratios (C:N) of the 'lignin' fraction are also presented

\begin{tabular}{|c|c|c|c|c|}
\hline Detritus & Age (mo) & 9 lignin & $g$ lignin- $N$ & $C: N$ \\
\hline \multirow[t]{5}{*}{ Spartina altemiflora (tall form) } & 0 & $4.4 \pm 0.1$ & $0.04 \pm<0.01$ & $53 \pm 5$ \\
\hline & 1 & $4.0 \pm 0.7$ & $0.04 \pm<0.01$ & $42 \pm 6$ \\
\hline & 5.5 & $4.6 \pm 0.1$ & $0.06 \pm 0.01$ & $32 \pm 3$ \\
\hline & 9.5 & 1.8 & $0.09 \pm 0.01$ & $20 \pm 1$ \\
\hline & 23 & $1.0 \pm 0.2$ & $0.01 \pm<0.01$ & $14 \pm<1$ \\
\hline \multirow[t]{2}{*}{ S. alterniflora (short form) } & 0 & $6.0 \pm 0.8$ & $0.07 \pm 0.01$ & $37 \pm 1$ \\
\hline & 13 & $2.9 \pm 0.3$ & $0.06 \pm 0.01$ & $19 \pm<1$ \\
\hline \multirow[t]{2}{*}{ S. patens } & 0 & $4.6 \pm 0.2$ & $0.05 \pm 0.01$ & $55 \pm 7$ \\
\hline & 23 & $3.0 \pm<0.1$ & $0.06 \pm<0.01$ & $23 \pm 1$ \\
\hline \multirow[t]{2}{*}{ Zostera marina } & 0 & $1.4 \pm 0.1$ & $0.05 \pm 0.01$ & $14 \pm<1$ \\
\hline & 4 & $1.6 \pm<0.1$ & $0.08 \pm 0.01$ & $9 \pm<1$ \\
\hline \multirow[t]{2}{*}{ Ulva lactuca } & 0 & $3.6 \pm 1.9$ & $0.02 \pm 0.01$ & 82 \\
\hline & 0.75 & $1.5 \pm 0.7$ & $0.02 \pm 0.01$ & $26 \pm 1$ \\
\hline \multirow[t]{2}{*}{ Gracilaria tikvahiae } & 0 & Undetectable & Undetectable & \\
\hline & 0.50 & $0.3 \pm 0.1$ & $0.01 \pm<0.01$ & $5 \pm<1$ \\
\hline \multirow[t]{2}{*}{ Fucus vesiculosis } & 0 & $12.3 \pm 1.5$ & $0.19 \pm 0.03$ & $28 \pm 1$ \\
\hline & 2 & $2.8 \pm 0.4$ & $0.03 \pm 0.01$ & $26 \pm<1$ \\
\hline
\end{tabular}




\section{Nitrogen associated with acid-refractory material}

Initial concentration of 'lignin'- $\mathrm{N}$ were highest in $\mathrm{Fu}$ cus vesiculosis, which also had the highest 'lignin' concentration (Table 6). Vascular plants had intermediate levels, and U. lactuca and G. tikvahiae were lowest. This pattern differed from the other cell wall fractions in which all algae were higher in nitrogen than marsh grasses.

Several types of detritus incorporated nitrogen into their 'lignin' during decay (Table 6). Tall Spartina alterniflora at 5.5 and $9.5 \mathrm{mo}$, S. patens at $23 \mathrm{mo}$ and Zostera marina at 4 mo contained greater than $100 \%$ of the initial pool of nitrogen associated with lignin.

We distinguished between the incorporation of nitrogen into lignin vs cellulose by comparing the increase in lignin-N pools during decay (Table 6 ) with changes in ADF-N (= 'lignin' + cellulose) pools at the same times (Table 5). The lignin- $\mathrm{N}$ pool in tall Spartina alterniflora increased $0.05 \mathrm{~g}$ per $100 \mathrm{~g}$ initial detritus from time 0 to 9.5 mo. This more than accounted for the increase of 0.04 $g$ in the ADF-N pool over the same time period. The incorporation of nitrogen into Zostera marina lignocellulose was also attributed to lignin rather than cellulose. Thus lignin or some similar highly refractory material rather than cellulose is responsible for the incorporation of nitrogen into lignocellulose during decay.

The nitrogen fraction of the 'lignin' was more refractory to decay than the carbon in 'lignin' in all types of detritus except Fucus vesiculosis. This can be seen in Table 6 by comparing the size of the lignin- $N$ pool with the lignin pool in old detritus and also by noting that the $C: N$ ratio was less in old detritus compared to new, except in F. vesiculosis.

\section{Soluble phenolic concentrations}

Differences in the initial concentrations of soluble phenolics among the different types of detritus covered almost 2 orders of magnitude (Fig. 5). The highest initial concentrations occurred in detritus from Zostera marina (ca $10 \%$ ) and Fucus vesiculosis (ca 5\%), intermediate concentrations were present in marsh grasses (ca 1\%) and lowest concentrations in the algae Ulva lactuca and Gracilaria tikvahiae (ca $0.3 \%$ ).

The rapidity of phenolic loss during decay varied among the different types of detritus, with vascular plant detritus maintaining larger phenolic pools than algae throughout decay (Fig. 5). Zostera marina lost little soluble phenolics during the first month of decay, and then lost phenolics rapidly. In contrast, the pool of soluble phenolics dropped very rapidly in Fucus vesiculosis even after only $2 \mathrm{wk}$ of decomposition. Less marked changes occurred in detritus from marsh grasses and the 2 other species of algae.

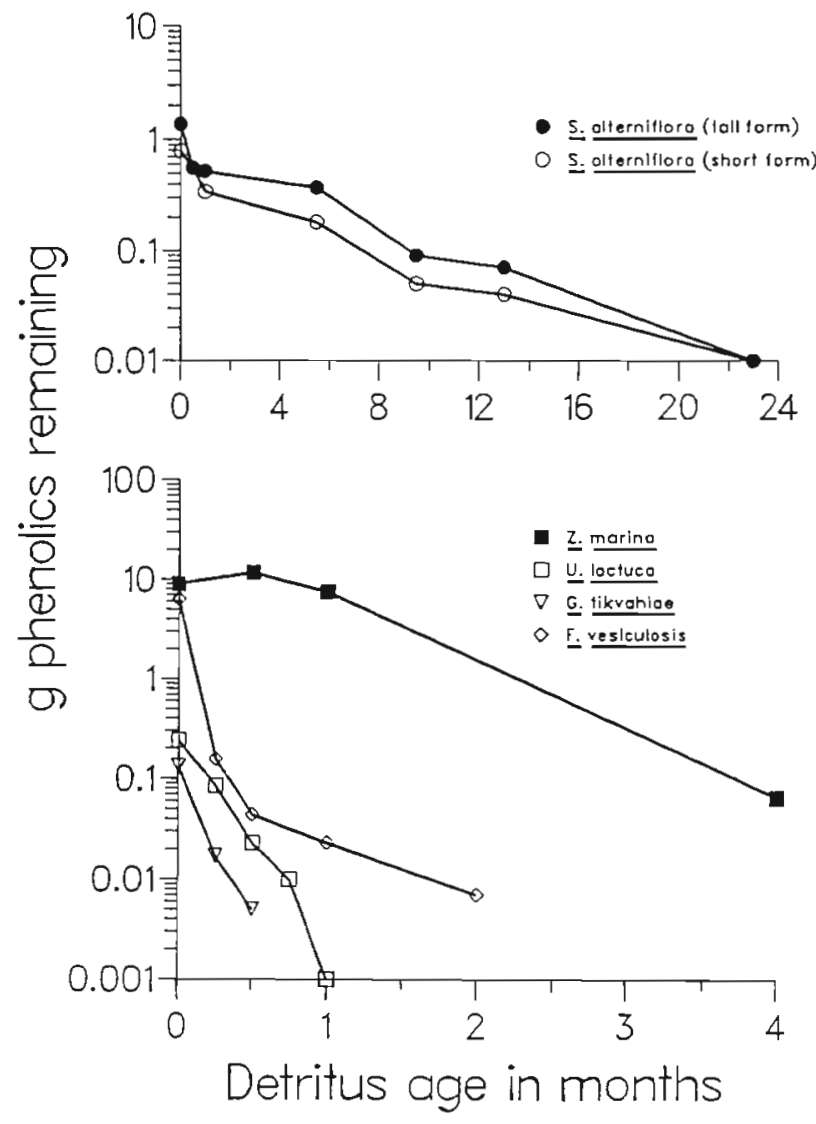

Fig. 5. Changes in the pools of total soluble phenolics in detritus during decay. Values are means \pm SE of duplicate or triplicate samples as indicated in 'Methods' Values of soluble phenolics for Spartina spp. taken from Wilson et al. (1985). Pool calculations normalized to $100 \mathrm{~g}$ organic matter of detritus at time 0 so that direct comparisons between different types of detritus can be made

\section{DISCUSSION}

\section{Effect of different types of defritus on nitrogen dynamics}

Detritus of marine algae, a submerged vascular plant, and salt marsh grasses showed characteristic differences in their decay rates and the size, lability, and turnover rates of their nitrogen and phenolic pools during in situ decay. The most consistent chemical difference between the marine algae and vascular plants was in the dynamics of nitrogen and amino acids in the cell wall during decay. The cell walls of vascular plants accumulate nitrogen relative to carbon during decay. In contrast, cell walls of algae do not accumulate nitrogen, and the high initial nitrogen concentrations in these cell walls is rapidly lost.

Our results were similar to those of terrestrial detritus, in that relative decay rates were related to the size and lability of nitrogen and phenolic pools. The 
green and red algae Ulva lactuca and Gracilaria tikvahiae produce detritus that decayed rapidly, probably due to low levels of phenolic constituents $k 1 \%$ AFDW) and large initial nitrogen pools that included soluble, protease refractory, and cell wall associated nitrogen and amino acids. Soluble nitrogenous and phenolic constituents were rapidly leached out within a few weeks, but even the nitrogen and amino acids associated with cell wall fractions of declined rapidly during decay. The percentage of cell wall material in $U$. lactuca measured as either NDF or ADF was similar to that of Zostera marina, but its more rapid decay rate and lack of even relative nitrogen accumulation during decay is probably related to its relatively simple cell wall structure that lacks phenolics (Siegel \& Siegel 1973).

Detritus of Fucus vesiculosis lost mass at about half the rate of the other 2 algae. Like Ulva lactuca and Gracilaria tikvahiae, this brown algae had relatively high levels of protease refractory and cell wall nitrogenous constituents, that were not particularly refractory, and its cell wall never showed the nitrogen enrichment characteristic of vascular plants. Its slower decay rates compared to the other algae were likely the result of smaller total nitrogen and amino acid pools and the presence, at least initially, of high concentrations of phlorotannins (Fig. 6; Ragan \& Glombitza 1986). These may reduce the activities of microbial cellulases and other degradative enzymes (Swain 1979, Horner et al. 1988). We suspect these polyphenols were the reason that virtually no amino acids were hydrolyzed by the protease throughout decay, since they likely bound both the protease itself and whatever available amino acids were present before senescence. The phlorotannins were rapidly leached out upon senescence, probably removing available amino acids in the process.

Phlorotannins and other phenolics have never been definitively isolated from algal cell walls (Ragan \& Glombitza 1986). Their absence from the cell wall may prevent Fucus vesiculosis and the other 2 species of algae in this study from incorporating $\mathrm{N}$ from outside or retaining internal $\mathrm{N}$.

The decay rate and the initial size and availability of the nitrogen pool of Zostera marina were intermediate between algae and marsh grasses. In contrast to the algal detritus incubated in the same habitat, nitrogen and amino acids became less available to decomposers and cell wall fractions became enriched in nitrogen relative to carbon. Z marina also differed from algae in containing relatively high levels of methanol extractable phenolics throughout decay. Although these are not tannins, the ortho-dihydroxy phenolic acids and flavonoids of Z. marina (Buchsbaum et al. 1990) are typically bioactive (Molgaard \& Ravn 1988, Horner et al. 1989) and may inhibit the activity of microbiai cellulases. Z. marina contained low concentrations of cell wall-bound phenolics (Table 4 ; and Harris \& Hartley 1980), which may explain why its cell wall decomposed slower than that of algae but faster than that of marsh grasses.

Salt marsh grases decayed the slowest and had the smallest initial nitrogen pools. Nitrogen and amino acids in marsh grasses were relatively refractory to protease and detergent extractions, and, like Zostera marina, were lost at a slower rate than detrital carbon. Periods of nitrogen and amino acid immobilization occurred during the decay of both Spartina alterniflora (tall form) and S. patens. The more rapid loss of amino acids compared to total nitrogen in the fiber fractions of these marsh grasses suggests that amino nitrogen associated with cell walls is undergoing some transformation into heterocyclic humic complexes during the decay of these species (Rice 1982).

\section{Phenolics, decomposition, and nitrogen immobilization}

Phenolic compounds may retard detrital nitrogen losses both directly and indirectly. Phenolics can act directly as a substrate for the incorporation of allochthonous proteins into detritus through binding to phenolic hydroxyl groups (Van Sumere et al. 1975, Rice 1982). Our data suggests that lignin and related phenolics were significant nitrogen-incorporating substrates in cell walls of vascular plant detritus. Absolute increases in nitrogen that occurred in the ADF fraction in Spartina alterniflora and Zostera marina could be entirely attributed to increases in nitrogen in the lignin fraction (Tables $5 \& 6$ ). Phenolics may also retard nitrogen losses indirectly by inhibiting microbial hydrolytic enzymes (Swain 1979), thus reducing the decay rates of cell walls. If decay rates are slow enough, then immobilization of nitrogen will occur because rates of nitrogen incorporation through chemical binding and microbial uptake may eventually exceed nitrogen losses through decomposition.

The importance of phenolics and other factors that reduce decay rates in determining whether nitrogen is incorporated into detritus was illustrated by the various types of detritus we studied. Periods of immobilization occurred only in Spartina patens and S. alterniflora, both of which had relatively slow decay rates. The nitrogen dynamics during the decay of $S$. patens in particular resembled that of typical terrestrial detritus in having an initially period of net nitrogen immobilization, in which nitrogen levels rose during decay to greater than $100 \%$ of that initially present, followed by mineralization (Melillo et al. 1982, Melillo \& Aber 
1984). The absolute increase in nitrogen in $S$. alterniflora detritus between 1 and 6 mo may have been due to very slow decomposition rates during winter. Newell et al. (1989) observed a period of nitrogen immobilization into standing dead $S$. alterniflora. $S$. alterniflora did immobilize nitrogen to greater than $100 \%$ initial levels during decay in microcosm studies in which decay rates were slower than in our field-incubated detritus (Rice \& Hanson 1984, Tenore et al. 1984).

The lack of net nitrogen immobilization in detritus of Zostera marina and algae may be related to their fast rates of decay as well as a reduced capacity for incorporating nitrogen. The reduction of overall detrital decay rates by phenolics is likely more important in determining whether nitrogen and other nutrients are immobilized than the rates of chemical binding of nutrients to phenolic compounds (or uptake by microbes).

\section{Carbon vs nitrogen limitation of detrital decomposition}

The lability of detrital carbon also influences loss and accumulation of nitrogen in detritus. Much of the carbon in vascular plant detritus is in refractory, high molecular weight polysaccharides and phenolics that gradually increase in concentration during decay as more labile constituents are removed (Hodson et al. 1984, Wilson et al. 1985). Tenore (1983) has suggested that detritivores feeding on such detritus are energy limited; in contrast, the relative lability of algal cell walls may lead to nitrogen limitation of algal detritivores. Our observations support this view. First, detrital carbon was lost more rapidly than detrital nitrogen in marsh grasses, but not in Zostera marina or algae. Since $Z$. marina does not contain true lignin, its cell wall is less refractory than that of terrestrial vascular plants and its $C$ : $N$ balance during decay would be atypical for a terrestrial plant. Second, pools of available amino acids persist longer in vascular plant detritus than in algae. In Spartina patens, our slowest decaying species, much of the nitrogen pool is still available to detritivores even in the latter stages of decay. This would suggest that at least some of the nitrogen in old vascular plant detritus (about $50 \%$ of the pool in $S$. patens) is potentially labile, but is not being used by decomposers.

Hemminga et al. (1988) found little available protein during decomposition of roots and rhizomes of Spartina anglica. Our results are not directly comparable to theirs, since we used shoots and leaves and our methods of extracting available nitrogen compounds differed. Nonetheless, it is possible that loss of available nitrogen compounds is more rapid in anaerobic conditions where the oxidative reactions necessary for phenolic binding are limited.

Proteins could be an energy source in vascular plant detritus, but may not be completely degraded to ammonia and carbon dioxide. Their remnants may still be measurable as amino acids and nitrogen in our assays. In anaerobic decay, where it is clear that energy is more limiting than nitrogen (Fenchel \& Blackburn 1978), substantial amounts of reduced nitrogen compounds are released by microbes (Mendelsohn et al. 1981).

Another possible explanation of why nitrogen decays less rapidly than carbon in vascular plants is that nitrogen is incorporated into refractory fractions in detritus (Benner et al. 1984, Rice \& Hanson 1984, Hemminga et al. 1988; Tables $3 \& 4$ of this study). Our evidence for incorporation was the presence of greater than $100 \%$ of the initial concentration of ADF-N and ADL-N in vascular plant detritus at various times during decay, Despite this incorporation, nitrogen associated with these refractory fractions never comprised more than half the total nitrogen pool even in later stages of decay (compare Fig. 2 and Table 3). The nitrogen that is added to detritus by microbial activity is not immediately refractory (Rice \& Hanson 1984). It is likely that a longer time scale of decay, such as in terrestrial plant decomposition, is required for the gradual incorporation and transformation of nitrogen into refractory complexes with lignocelluloses to be numerically more significant.

\section{Implications for other trophic levels}

The differences we found in decay rates, nitrogen dynamics, and nutritive quality of the different types of detritus have potentially significant consequences for the ecosystem. Thayer (1974) suggested that the cycles of primary productivity of phytoplankton could be in part controlled by cycles of immobilization and mineralization of nitrogen by microbes breaking down detritus. Sites where most dead organic matter originates from green and red algae should furnish nutrient-rich detritus with a very high rate of turnover and nitrogen mineralization. Where terrestrial or marsh grass detritus dominates, slower decay and regeneration of nutrients, plus lower quality of food for decomposers, would be the rule.

Acknowledgements. This research was supported by NSF grant OCE 8315917. We thank D. Gifford for the use of her land on Great Sippewissett Marsh. B. Woodward of the Woods Hole Oceanographic Institution carried out the total nitrogen analyses. P. Hall provided advice on the statistical analyses. J. Wilson and 3 anonymous reviewers offered helpful suggestions for improving the manuscript. 


\section{LITERATURE CITED}

Allen, S. E., Grimshaw, H. M., Parkinson, J. A., Quarmby, C. (1974). Chemical analysis of ecological materials. Blackwell Scientific, Oxford

Aumen, N. G., Bottomley, P. J., Gregory, S. V. (1985). Impact of nitrogen and phosphorus ${ }^{14} \mathrm{C}$ lignocellulose decomposition by stream wood microflora. Appl. environ. Microbiol. 49: 1113-1118

Benner, R., Maccubbin, A. E., Hodson, R. E. (1984). Preparation, characterization and microbial degradation of specifically radiolabeled $\left[{ }^{14} \mathrm{C}\right]$ lignocelluloses from marine and freshwater macrophytes. Appl. environ. Microbiol. 47: 381-389

Buchsbaum, R., Short, F. T., Cheney, D. (1990). Phenolic nitrogen interactions in eelgrass, Zostera marina L.: possible implications for disease resistance. Aquat Bot. 37: 291-297

Choo, G. M., Waterman, P. G., McKey, D. B., Gartlan, J. S (1981). A simple enzyme assay for dry matter digestibility and its value for studying food selection by generalist herbivores. Oecologia (Berl.) 49: 170-178

Fenchel, T. (1977). Aspects of the decomposition of seagrasses. In: McRoy, C. P., Helferrich, C. (eds.) Seagrass ecosystems: a scientific perspective. Marcel Dekker, New York, p. 123-145

Fenchel, T., Blackburn, T. H. (1978). Bacteria and mineral cycling. Academic Press, New York

Godshalk, G. L., Wetzel, R. G. (1978). Decomposition of aquatic angiosperms. II. Particulate components. Aquat. Bot. 5: 301-325

Goering, H. K., Van Soest, P. J. (1970). Forage fiber analysis (apparatus, reagents, procedures, and some applications) U.S. Dept. Agric. Agric. Res. Serv. Agric. Handbook 379

Harris, P. J., Hartley, R. D. (1980). Phenolic constituents of cell walls of monocotyledons. Biochem. Syst. Ecol 8: 153-160

Hemminga, M. A., Kok, C. J., de Munck, W. (1988). Decomposition of Spartina anglica roots and rhizomes in a salt marsh of Westerschelde Estuary. Mar. Ecol. Prog. Ser. 48: $175-184$

Hobbie, J. E., Lee, C. (1980). Microbial production of extracellular material: importance in benthic ecology. In: Tenore, K., Coull, B. C. (eds.) Marine benthic dynamics. Univ of S. Carolina Press, Columbia, p. 341-346

Hodson, R. E., Christian, R. R., Maccubbin, A. E. (1984) Lignocellulose and lignin in the salt marsh grass Spartina alterniflora: initial concentrations and short-term postdepositional changes in detrital matter. Mar Biol. 81: 1-7

Horner, J. D., Gosz, J. R., Cates, R. G. (1988). The role of carbon-based secondary metabolites in decomposition. Am. Nat. 132: 869-883

Lee, C., Howarth, B., Howes, B. (1980). Sterols in decomposing Spartina alterniflora and the use of ergosterol in estimating the contribution of fungi to detrital nitrogen. Limnol. Oceanogr. 25: 290-303

Marinucci, A. C., Hobbie, J. E., Helferich, J V. K. (1983) Effect of litter nitrogen on decomposition and microbial biomass in Spartina alterniflora. Microbiol. Ecol. 9: 27-40

Marks, D. L., Buchsbaum, R., Swain, T (1985). Measurement of total protein in plant samples in the presence of tannins Analyt. Biochem. 147: 136-143

McNeill, M., Carvill, A. G., Fry, S. C., Albersheim, P. (1984) Structure and function of the primary cell wall in plants. Ann. Rev. Biochem. 53: 625-663

Melillo, J. M., Aber, J. D. (1984). Nutrient immobilization in decaying litter: a example of carbon-nitrogen interactions. In: Cooley, J. H., Golley, F. B. (eds.) Trends in ecological research for the 1980 's. Plenum Press, New York, p. $193-215$

Melillo, J. M., Aber, J. D., Muratore, J. F. (1982). Nitrogen and lignin control of hardwood leaf litter decomposition dynamics. Ecology 63: 621-626

Mendelsohn, I. A., McKee, K. L., Patrick, W. H. (1981). Oxygen deficiency in Spartina alterniflora roots: metabolic adaptations to anoxia. Science $214: 439-441$

Molgaard, P., Ravn, H. (1988). Evolutionary aspects of caffeoyl ester distribution in dicotyledons. Phytochem. 27 2411-2421

Newell, S. Y., Fallon, R. D., Miller, J. D. (1989). Decomposition and microbial dynamics for standing, naturally positioned leaves of the salt-marsh grass Spartina alterniflora. Mar. Biol. 101: 471-481

Odum, W. E., Kirk, P. W., Zieman, S. C. (1979). Non-protein nitrogen compounds associated with particles of vascular plant detritus. Oikos 32: 363-367

Paerl, H. (1984). Alteration of microbial metabolic activities in association with detritus. Bull. mar Sci. 35: 393-408

Ragan, M. A., Glombitza, K.-W. (1986). Phlorotannins, brown algae polyphenols. Prog. Phycol. Res. 4: 129-241

Rice, D. L. (1982). The detritus nitrogen problem. New observations and perspectives from organic geochemistry. Mar Ecol. Prog. Ser. 9: 153-162

Rice, D. L., Hanson, R. B. (1984). A kinetic model for detritus nitrogen: role of the associated bacteria in nitrogen accumulation. Bull mar. Sci. 35: 326-340

Rietsma, C., Valiela, I., Buchsbaum, R. (1988). Effect of detrital chemistry on growth and food choice in the salt marsh snail. Ecology 69: 261-266

Siegel, S. M., Siegel, B. Z. (1973). The chemical composition of algal cell walls. Crit. Rev. Microbiol. 3: 1-26

Swain, T. (1979). Tannins and lignins. In: Rosenthal G. E. Janzen, D. H. (eds.) Herbivores: their interactions with secondary plant metabolites. Academic Press, New York, p. $657-682$

Swain, T., Goldstein, J. (1964). The quantitative analysis of phenolic compounds. In: Pridham, J. B. (ed.) Methods in polyphenol chemistry. MacMillan, New York, p. 131-146

Tenore, K (1983). What controls the availability to animals of detritus derived from vascular plants: organic nitrogen enrichment or caloric availability? Mar. Ecol. Prog. Ser. 10: 307-309

Tenore, K. R., Hanson, R. B., McClain, J., Maccubbin, A. E., Hodson, R. E. \{1984\}. Changes in the composition and nutritional value to a benthic deposit feeder of decomposing detritus pools. Bull. mar. Sci. 35: 299-311

Tenore, K. R. Rice, D. L. (1980). Trophic factors affecting secondary production of deposit feeders. In: Tenore, K. R. Coull, B. C. (eds.) Marine benthic dynamics. Univ. of. S. Carolina Press, Columbia, p. 325-340

Thayer, G. W (1974). Identity and regulation of nutrients limiting phytoplankton production in shallow estuaries near Beaufort, N. C. Oecologia (Berl.) 14: 75-92

Thayer, G. W., Kenworthy, W. J., Fonseca, M. S. (1984). The ecology of eelgrass meadows of the Atlantic coast: a community profile. U.S. Fish Wildl. Serv. FWS/OBS-84/24. $85 \mathrm{pp}$.

Thorne-Miller, B., Harlin., M. M. (1984). The production of Zostera marina and other submerged macrophytes in a coastal lagoon in Rhode Island. Botanica mar. 27: 539-546

Valiela, I., Teal, J. M., Volkmann, S., Van Etten, R., Allen, S. (1985). Decomposition in salt marsh ecosystems: the phases and major factors affecting the disappearance of above-ground organic matter. J. exp. mar Biol. Ecol. 89: $1-26$ 
Van Sumere, C. F., Albrecht, J., DeDonder, A., De Pooter, H., Pe, I. (1975). Plant proteins and phenolics. In: Harborne, J. B., Van Sumere, C. F. (eds.) The chemistry and biochemistry of plant proteins. Academic, New York, p. $211-264$

Wheeler, P. A., Kirchman, D. L. (1986). Utilization of inorganic

This article was presented by S. W. Nixon, Narrangansett, Rhode Island, USA and organic and organic nitrogen by bacteria in marine systems. Limnol. Oceanogr. 31: 998-1009

Wilson, J. O., Buchsbaum, R., Valiela, I., Swain, T. (1985). Decomposition in salt marsh ecosystems: phenolic dynamics during decay of litter of Spartina alterniflora. Mar Ecol. Prog. Ser 29: 177-187

Manuscript first received: November 15, 1988

Revised version accepted: February 26, 1991 